\title{
KELAYAKAN MEDIA PEMBELAJARAN BERBASIS LABORATORIUM VIRTUAL PADA SUB MATERI KIMIA UNSUR PERIODE KETIGA
}

\author{
Aida Zahwa Talia Dzikro ${ }^{1}$, Kusumawati Dwiningsih ${ }^{2 *}$ \\ ${ }^{12}$ Program Studi Pendidikan Kimia, Universitas Negeri Surabaya. Jalan Ketintang Gedung D1, \\ Surabaya 60231, Indonesia. \\ * Coressponding Author. E-mail: kusumawatidwiningsih@unesa.ac.id
}

Received: 13 Januari 2021

Accepted: 25 Juli 2021

doi: 10.29303/cep.v4i2.2389

Published: 14 Agustus 2021

\begin{abstract}
Abstrak
Penelitian dan pengembangan ini bertujuan untuk mengetahui kelayakan media pembelajaran berbasis laboratorium virtual pada materi kimia unsur sub materi periode ketiga. Kelayakan media pembelajaran diperoleh dari 2 kriteria yakni validitas media berdasarkan penilaian validator dan keefektifan media berdasarkan peningkatan hasil belajar peserta didik. Jenis penelitian yang digunakan adalah model penelitian dan pengembangan $4 \mathrm{P}$ (pendefinisian, perancangan, pengembangan, dan penyebarluasan), namun hanya dibatasi pada tahap uji coba produk. Instrumen penelitian yang digunakan meliputi lembar telaah media, lembar validasi media, serta soal pretest dan posttest. Hasil penelitian yang dilakukan memperoleh persentase kevalidan isi sebesar $85,12 \%$ dan pada validitas konstruk sebesar $86,73 \%$ yang dikategorikan sangat valid. Persentase keefektifan media berdasarkan peningkatan hasil belajar peserta didik diperoleh skor $\mathrm{N}$-gain sebesar $87,14 \%$ yang dikategorikan tinggi. Berdasarkan hasil penelitian tersebut, maka media pembelajaran berbasis laboratorium virtual layak digunakan sebagai media pembelajaran pada materi kimia unsur sub materi periode ketiga.
\end{abstract}

Kata Kunci: media pembelajaran, laboratorium virtual, kimia unsur periode ketiga

\section{Feasibility of Virtual Laboratory-Based Learning Media in The Third Period Sub- Material Chemistry Element}

\begin{abstract}
This research and development aim to determine the feasibility of virtual laboratory-based learning media in the third-period sub-material chemistry element. The feasibility of learning media is obtained from 2 criteria, namely media validity based on the validator's assessment, and media effectiveness based on improving student learning outcomes. The type of research used is the $4 P$ research and development model (definition, design, development, and dissemination), but it is only limited to the product trial stage. The research instruments used included media review sheets, media validation sheets, and pretest and posttest questions. The research obtained a percentage of content validity of $85.12 \%$ and the construct validity of $86.73 \%$, categorized as very valid. The percentage of media effectiveness based on the increased in student learning outcomes obtained scores $N$-gain with a range of 75-100\%, categorized as high. Based on the results of this study, the virtual laboratory-based learning media is feasible to use as a learning media on the third-period sub-material chemistry element. Keywords: learning media, virtual laboratory, third-periods element chemistry.
\end{abstract}

\section{PENDAHULUAN}

Ilmu kimia merupakan ilmu yang mempunyai peranan penting dalam kehidupan masyarakat karena kita tidak akan terlepas dari unsur-unsur kimia dalam kehidupan sehari-hari (Mangengke dan Dwiningsih, 2021). Namun sampai saat ini, Ilmu kimia masih dianggap salah satu pelajaran yang tidak mudah untuk dipahami karena menurut Alponita (2018) menyatakan bahwa ilmu kimia merupakan bidang studi yang sifatnya abstrak dan juga menekankan konsep hingga ke tingkat mikroskopik (molekuler) simbolik, dan juga tergolong mata pelajaran yang tidak mudah. Selain itu ilmu kimia juga 


\section{Chemistry Education Practice, 4 (2), 2021 - 161}

Dzikro, Dwiningsih

membahas tentang teori, aturan, fakta, deskripsi dan peristilahan (Raffani \& Dwiningsih, 2016).

Berdasarkan silabus mata pelajaran kimia dalam kurikulum 2013 yang berlaku, kimia unsur adalah salah satu materi pelajaran yang diberikan kepada peserta didik kelas XII MIPA pada semester ganjil. Dalam mempelajari materi kimia unsur pokok bahasan periode ketiga membahas tentang karakteristik memuat materi yang banyak mengenai sifat fisika dan kimia, kegunaan, serta proses pembuatannya, sehingga tidak hanya dengan menghafal tentang pengertian suatu konsep dan aplikasinya, namun diperlukan proses berpikir dalam memahaminya (Mangengke \& Dwiningsih, 2020). Hal ini dikarenakan materi kimia unsur periode ketiga tidak hanya berupa definisi tetapi juga berupa konsep abstrak seperti konsep tentang reaksi-reaksi kimianya (Arham \& Dwiningsih, 2016).

Materi kimia unsur periode ketiga dianggap materi yang sulit. Hal tersebut dibuktikan oleh hasil angket pra penelitian sebanyak $75 \%$ peserta didik menyatakan bahwa materi kimia unsur sulit. Hasil angket pra penelitian di MA Al-Madany Gresik sebanyak $100 \%$ peserta didik menyatakan bahwa guru menyampaikan materi dengan menggunakan metode ceramah dan media yang digunakan saat pembelajaran sebanyak $100 \%$ peserta didik menyatakan menggunakan LKPD.

Dari hasil wawancara beberapa guru kimia di MA Al-Madany Gresik, diperoleh informasi bahwa dalam proses pembelajaran kimia unsur, guru hanya menggunakan LKPD dan buku paket serta waktu pembelajaran kimia di kelas terbatas, sehingga mata pelajaran kimia unsur periode ketiga terkadang tidak disampaikan oleh guru karena dapat dibaca sendiri oleh peserta didik. Berdasarkan hasil angket pra-penelitian didapati data bahwa beberapa peserta didik di MA AlMadany menyatakan bahwa mata pelajaran kimia tidak mudah untuk dipahami. Hal tersebut dikarenakan strategi yang digunakan dalam pembelajaran kimia masih belum bisa menumbuhkan motivasi dan rasa keingintahuan peserta didik untuk lebih mempelajari kimia (Arham \& Dwiningsih, 2016).

Berdasarkan tinjauan beberapa jurnal mengenai pembelajaran kimia terhadap peserta didik, memperlihatkan bahwa materi kimia meliputi konsep partikel dasar materi yang tidak dapat dilihat secara langsung oleh peserta didik (submikroskopik) maka banyak peserta didik menganggap kimia itu abstrak atau sulit (Setiawan \& Dwiningsih, 2020). ada level submikroskopik ini sangat penting dalam memahami kimia dimana penjelasan fenomena kimia bergantung level submikroskopik pertikel yang digambarkan secara simbolik (Chen dkk., 2018)

Berdasarkan hasil pra-penelitian di MA Al-Madany Gresik menunjukan bahwa sebanyak $100 \%$ peserta didik ingin melakukan praktikum pada materi kimia unsur, namun metode praktikum tidak pernah dilakukan. Hal ini dikarenakan oleh berbagai kendala seperti kurangnya fasilitas laboratorium dan terbatasnya alokasi waktu pembelajaran. Hal tersebut mengakibatkan materi kimia unsur dinilai sebagai konsep yang abstrak sehingga menyebabkan pemahaman konsep peserta didik menjadi rendah (Mangengke \& Dwiningsih, 2020). Praktikum adalah salah satu upaya yang digunakan untuk membuktikan fakta yang terdapat dalam teori, dimana peserta didik diberikan kesempatan dalam menemukan sendiri fakta untuk meningkatkan pemahaman (Setiawan, 2019).

Kegiatan praktikum saat mempelajari kimia unsur tidak pernah dilakukan di sekolah MA Al-Madany. Hal ini dibuktikan dengan hasil angket pra-penelitian bahwa sebanyak $100 \%$ peserta didik tidak pernah melakukan praktikum materi kimia unsur. Berdasarkan wawancara dengan guru kimia MA Al-Madany, kegiatan praktikum tidak dilakukan karena kendala seperti kurangnya fasilitas laboratorium yang disediakan. Berdasarkan pernyataan di atas menyebabkan peserta didik kesulitan untuk memahami materi sehingga peserta didik hanya dapat mempelajari materi kimia unsur dengan hanya menghafal. Berdasarkan pernyataan di atas maka dapat dikembangkan laboratorium virtual sebagai media pembelajaran yang dapat digunakan oleh peserta didik untuk belajar menggunakan digital sesuai era 4.0.yang menggunakan digital sebagai alat untuk belajar.

Laboratorium virtual adalah sebuah media untuk menciptakan lingkungan interaktif dan dapat melakukan percobaan simulasi percobaan (Mangengke \& Dwiningsih, 2020). Media ini sangat praktis dan dapat membantu peserta didik sebelum melakukan praktikum yang sebenarnya. Menurut Dwiningsih dkk. (2018) mengatakan bahwa penggunaan laboratorium virtual sebagai media pembelajaran apabila diterapkan dalam kegiatan belajar mengajar tergolong sangat praktis. Laboratorium Virtual juga efektif untuk membuat peserta didik kenal dengan lingkungan laboratorium, terutama untuk peserta didik yang 
tidak memiliki kesempatan untuk menjelajahi laboratorium sebelumnya (Herga dkk., 2016).

Media pembelajaran berbasis laboratorium virtual sebenarnya bukan merupakan hal yang baru, namun masih terdapat peserta didik yang belum mengenal media ini. Hal tersebut dapat dibuktikan dengan hasil angket pra penelitian di MA Al-Madany bahwa sebanyak $100 \%$ peserta didik tidak mengetahui media laboratorium virtual. Dalam pembelajaran kimia di sekolah, media jenis ini tidak pernah digunakan dan menurut hasil angket pra-penelitian menyatakan bahwa sebanyak $100 \%$ peserta didik setuju jika diberikan media pembelajaran berbasis laboratorium virtual untuk digunakan dalam pembelajaran kimia unsur.

Dari hasil wawancara terhadap guru kimia didapatkan informasi bahwa peserta didik jenjang MA memiliki rentang usia antara 15-18 tahun, dimana termasuk dalam tahap operasional formal menurut teori belajar kognitif oleh Piaget (Dwiningsih dkk., 2018). Peserta didik mampu berpikir secara abstrak dan peserta didik mampu untuk membuat kesimpulan dari informasi yang didapatkan. Hal tersebut berarti bahwa peserta didik mampu dalam memanfaatkan teknologi untuk mengembangkan pengetahuan.

Berdasarkan latar belakang yang telah diuraiakan, maka peneliti perlu mengembangkan media pembelajaran berbasis laboratorium virtual pada sub materi kimia unsur periode ketiga yang layak dan efektif digunakan dalam proses belajar mengajar. Hal ini dilakukan untuk meningkatkan hasil belajar peserta didik pada materi kimia unsur periode ketiga.

\section{METODE}

Metode yang digunakan dalam penelitian ini yakni model penelitian dan pengembangan $4 \mathrm{P}$ oleh Ibrahim (2015), meliputi (1) pendefinisian, (2) perancangan, (3) pengembangan, (4) serta penyebarluasan. Namun, penelitian ini hanya dibatasi pada tahap pengembangan. Tahap penyebarluasan tidak dilakukan. Sasaran penelitian ini dilakukan terhadap peserta didik MA Al-Madany sebanyak 12 peserta didik. Langkah-langkah penelitian dapat dilihat pada gambar 1.

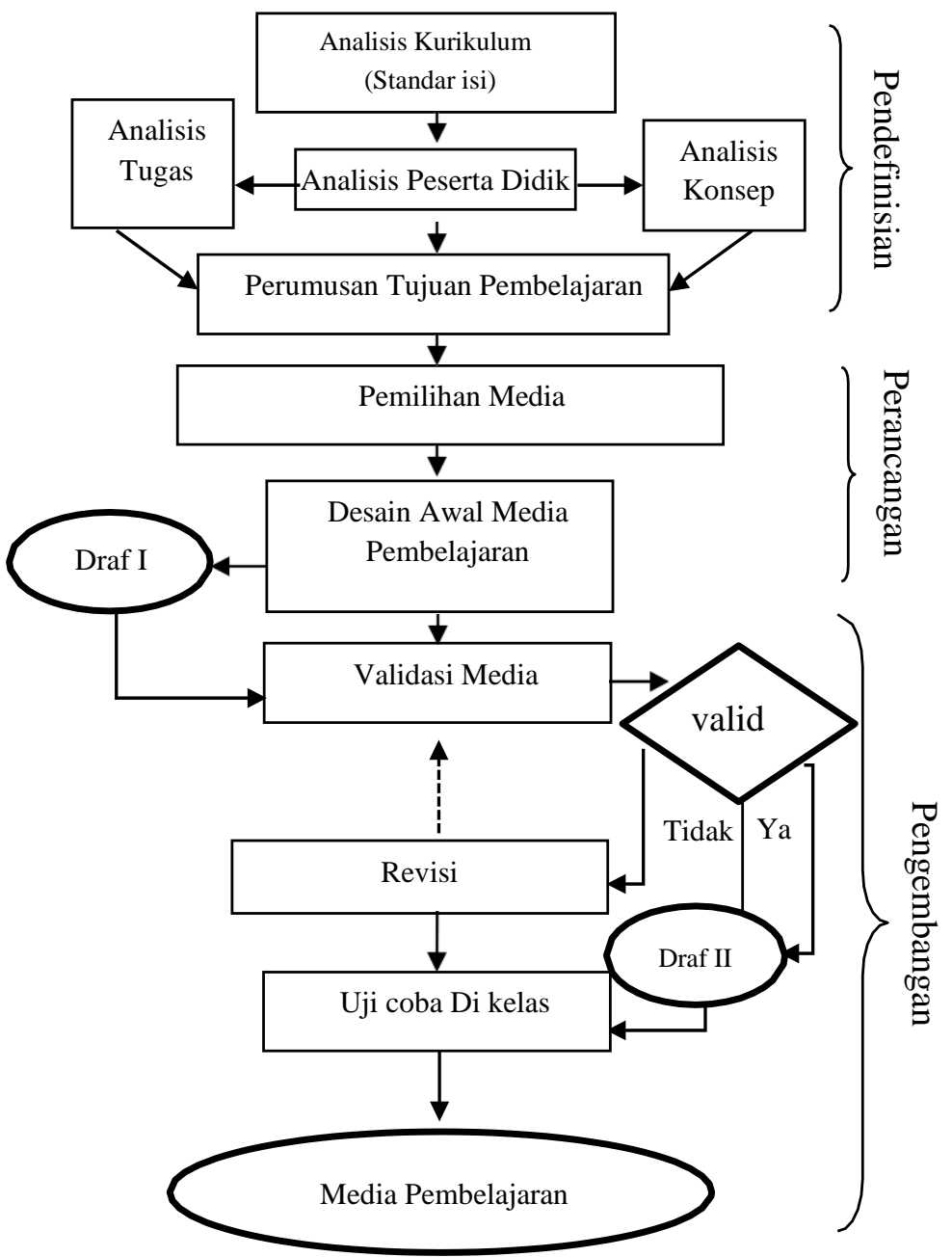

Gambar 1. Adaptasi Model Pengembangan Perangkat 4P (3P) (Ibrahim, 2015)

Pendefinisian adalah tahap pertama yang memiliki tujuan untuk menetapkan sebuah syarat dan juga batasan yang digunakan dalam materi pembelajaran terhadap media yang akan dikembangkan. Tahap ini memiliki beberapa bagian diantaranya analisis kurikulum, analisis peserta didik, analisis tugas, analisis konsep, serta merumuskan tujuan pembelajaran.

Perancangan adalah tahap kedua setelah melakukan tahap pendefinisian. Tahap ini dilakukan untuk penyusunan media dan desain awal media pembelajaran. Hasil dari tahap ini dinamakan dengan draf I yang akan ditelaah oleh dosen kimia. Hasil dari telaah berupa komentar untuk media tersebut yang selanjutnya akan dilakukan revisi. Hasil revisi dari telaah tersebut berupa draft II. Daft II akan diberikan kepada validator untuk dilakukan validasi media sebelum dilakukan uji coba terhadap peserta didik. 


\section{Chemistry Education Practice, 4 (2), 2021 - 163}

Dzikro, Dwiningsih

Penelitian ini didesain dengan menggunakan penelitian one-group-pretset-posttest-design.

\section{Kevalidan Media Laboratorium Virtual}

Kevalidan media pembelajaran berbasis laboratorium virtual ditinjau dari hasil validitas yang telah dinilai oleh tiga validator yaitu dua dosen kimia dan satu guru kimia. Pada lembar validasi ini terdapat dua aspek yaitu aspek validitas isi dan validitas konstruk. Persentase perhitungan validitas yang diperoleh dihitung dengan menggunakan perhitungan skala Likert yang dapat dilihat pada tabel 1 di bawah ini:

Tabel 1. Skala Likert

\begin{tabular}{cc}
\hline Penilaian & Nilai Skala \\
\hline Buruk sekali & 1 \\
Buruk & 2 \\
Cukup & 3 \\
Baik & 4 \\
Baik sekali & 5
\end{tabular}

(Riduwan, 2010).

Rumus perhitungan persentase data yang diperoleh dengan skala Likert menggunakan perhitungan sebagai berikut:

$$
\mathrm{P}(\%)=\frac{\text { Sskor hasil pengambilan data }}{\text { skor maksimum }} \times 100 \%
$$

Skor maksimum $=$ skor tertinggi tiap item $\mathrm{x}$ jumlah validator

Hasil yang didapatkan pada penilaian setiap aspek yang dinilai oleh dua dosen kimia dan satu guru kimia dianalisis dengan menggunakan interpretasi skor pada tabel 2 untuk mengetahui kevalidan media pembelajaran berbasis laboratorium virtual yang dikembangkan.

Tabel 2. Kriteria Interpretasi Skor

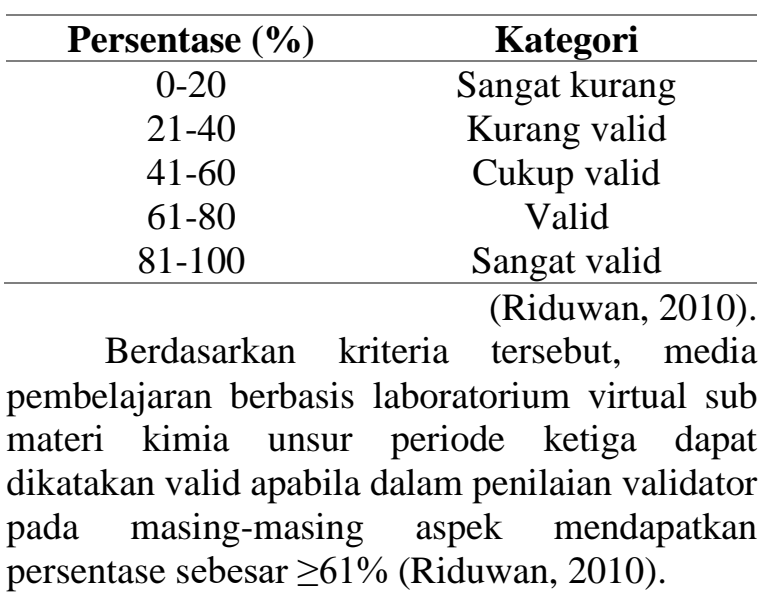

\section{Keefektifan Media Laboratorium Virtual}

Keefektifan media pembelajaran berbasis laboratorium virtual ditinjau dari peningkatan hasil belajar kimia unsur periode ketiga dari 12 peserta didik MA Al-Madany di Gresik. Metode penelitian didesain menggunakan penelitian onegroup-pretest-posttest-design. Desain penelitian ini peserta didik diberikan soal pretest terlebih dahulu sebelum diberikan media pembelajaran berbasis laboratorium virtual sub kimia unsur periode ketiga, kemudian setelah diberikan media pembelajaran berbasis laboratorium virtual pada materi kimia unsur periode ketiga peserta didik diberikan soal posttest yang ditunjukkan seperti persamaan di bawah ini (Sugiyono, 2013):

$$
\mathrm{O}_{1} \mathrm{X} \mathrm{O}_{2}
$$

Keterangan:

$\mathrm{O}_{1}=$ Pemberian soal pretest untuk mengetahui kemampuan awal peserta didik sebelum diberikan media pembelajaran.

$\mathrm{X}=$ Penggunaan media pembelajaran.

$\mathrm{O}_{2}=$ Pemberian soal posttest untuk mengetahui kemampuan peserta didik setelah diberikan media pembelajaran.

Rumus perhitungan persentase data yang diperoleh untuk menentukan peningkatan hasil belajar peserta didik pada materi kimia unsur periode ketiga diukur dengan menggunakan nilai pretest dan nilai posttest dengan menggunakan rumus sebagai berikut:

$$
N \text { - gain }=\frac{\text { nilai posttest-nilai pretest }}{\text { nilai maksimum-nilai pretest }}
$$

Hasil yang didapatkan kemudian dianalisis dengan menggunakan interpretasi skor n-gain pada tabel 3 berikut:

Tabel 3. Interpretasi Skor $N$-gain

\begin{tabular}{cc}
\hline Nilai $\boldsymbol{N}$-gain $(\mathrm{g})$ & Kategori \\
$\mathrm{g} \geq 0,7$ & Tinggi \\
$0,7>\mathrm{g} \geq 0,3$ & Sedang \\
$\mathrm{g}<0,3$ & Kurang \\
\hline & (Hake, 1998).
\end{tabular}

Berdasarkan kategori tersebut, peserta didik dapat dikatakan menguasai materi dengan penggunaan media pembelajaran berbasis laboratorium virtual sub materi kimia unsur periode ketiga ketika skor $N$-gain $\geq 0,7$ atau $\geq$ $70 \%$ sehingga media pembelajaran berbasis laboratorium virtual sub materi kimia unsur dapat dikatakan efektif.

\section{HASIL DAN PEMBAHASAN}

\section{Tahap Pendefinisian (Define)}

Tahap pendefinisian bertujuan untuk mendefinisikan dan menetapkan syarat-syarat serta batasan masalah yang diperlukan dalam pengembangan media pembelajaran berbasis 
laboratorium virtual. Pada tahap ini terdapat lima langkah, yaitu: 1) analisis kurikulum, 2) analisis peserta didik, 3) analisis tugas, 4) analisis konsep, dan 5) merumuskan tujuan pembelajaran.

Analisis kurikulum bertujuan untuk menganalisis dan menetapkan masalah yang dihadapi dalam pelaksanaan pembelajaran materi kimia unsur periode ketiga di sekolah. Kurikulum yang digunakan di MA Al-Madany adalah kurikulum 2013 revisi. Berdasarkan wawancara dengan guru kimia didapatkan hasil bahwa pembelajaran kimia unsur di sekolah dilaksanakan dengan menggunakan metode ceramah. Hal tersebut menyebabkan materi kimia sangat sulit untuk dipahami oleh peserta didik. Berdasarkan uraian tersebut maka dapat dikembangkan media pembelajaran berbasis laboratorium virtual dalam memahami materi kimia unsur periode ketiga.

Analisis peserta didik bertujuan untuk memahami karakteristik peserta didik sehingga dalam mengembangkan media pembelajaran berbasis laboratorium virtual sesuai dengan karakteristik peserta didik tersebut. Berdasarkan wawancara terhadap guru kimia diketahui bahwa umur peserta didik di sekolah MA Al-Madany berusia dalam rentang usia 15-18 tahun, dimana rentang usia tersebut termasuk ke dalam tahap operasional formal menurut teori belajar kognitif piaget. Pada tahap ini peserta didik mampu untuk berpikir secara abstrak sehingga peserta didik mampu untuk menganalisis dan memberikan kesimpulan terhadap persoalan yang dihadapi (Slavin, 2009).

Analisis tugas bertujuan untuk
mengidentifikasi materi yang akan dikembangkan dalam media pembelajaran berbasis laboratorium virtual dimana materi tersebut relevan dengan kompetensi dasar dan indikator. Pada tahap ini harus dilakukan untuk mengidentifikasi tahapan yang harus dilakukan oleh peserta didik untuk mempelajari materi kimia unsur periode ketiga. Tahapan ini harus dilakukan secara sistematis agar tujuan pembelajaran dapat terlaksana dengan baik.

Analisis konsep bertujuan untuk mengidentifikasi konsep pada materi kimia unsur periode ketiga yang akan disajikan dalam media laboratorium virtual, dimana konsep tersebut disusun secara matematis dan relevan. Konsepkonsep yang terdapat dalam media pembelajaran berbasis laboratorium virtual yang dikembangkan berupa konsep sifat fisika unsur-unsur periode ketiga, sifat kimia unsur-unsur periode ketiga, serta percobaan sifat-sifat pada unsur-unsur periode ketiga.

Merumuskan tujuan digunakan untuk menetapkan tujuan yang akan dicapai dari pembuatan media pembelajaran berbasis laboratorium virtual yang dikembangkan. Tujuan yang dicapai dapat dirumuskan berdasarkan pada analisis kurikulum, analisis peserta didik, analisis tugas, dan analisis konsep yang telah diuraikan. Media pembelajaran berbasis laboratorium virtual yang dikembangkan dalam tujuan pembelajaran yakni 1) Peserta didik dapat mensimulasikan percobaan penentuan sifat-sifat unsur periode ketiga. 2) Peserta didik dapat memahami sifat-sifat dari unsur periode ketiga.

\section{Tahap Perancangan (Design)}

Tahap perancangan terbagi menjadi dua tahapan, yakni penyusunan media dan desain awal media pembelajaran. Pada tahap pertama yakni tahap penyusunan media yang bertujuan untuk menyesuaikan media dengan materi dan karakterisik peserta didik sehingga indikator pembelajaran yang digunakan akan tercapai. Pembuatan media pembelajaran berbasis laboratorium virtual menggunakan aplikasi berbasis komputer yakni Adobe Flash Professional CS6.

Pada tahap kedua yaitu desain awal media pembelajaran dimana media harus berisikan materi yang benar dan sesuai dengan kaidah ilmu. Komponen laboratorium virtual meliputi format tampilan media, materi, gambar, animasi, video, serta backsound. Adapun rancangan desain laboratorium virtual tersebut terdiri atas 1) halaman pembuka, 2) menu utama, 3) menu petunjuk, 4) menu tujuan, 5) menu materi, 6) menu alat dan bahan, 7) menu alur percobaan, 8) menu praktikum.

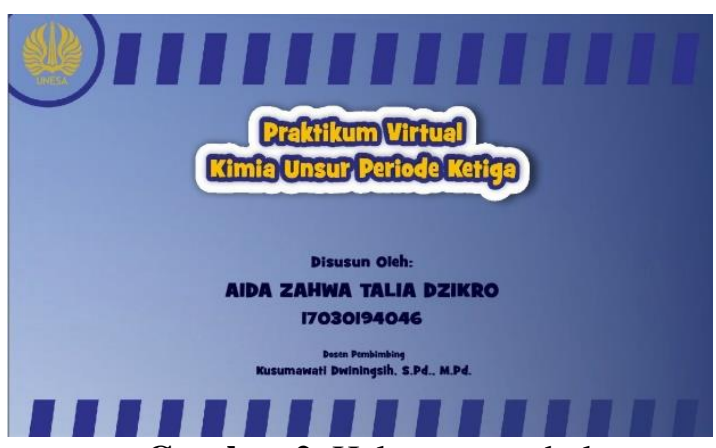

Gambar 2. Halaman pembuka laboratorium virtual 
Chemistry Education Practice, 4 (2), 2021 - 165

Dzikro, Dwiningsih

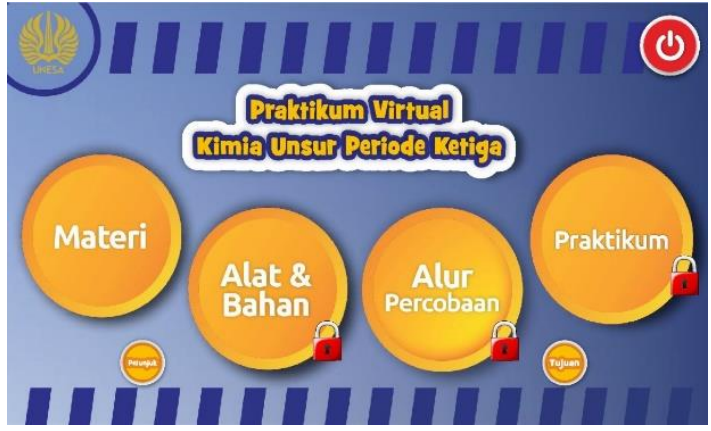

Gambar 3. Menu utama laboratorium virtual

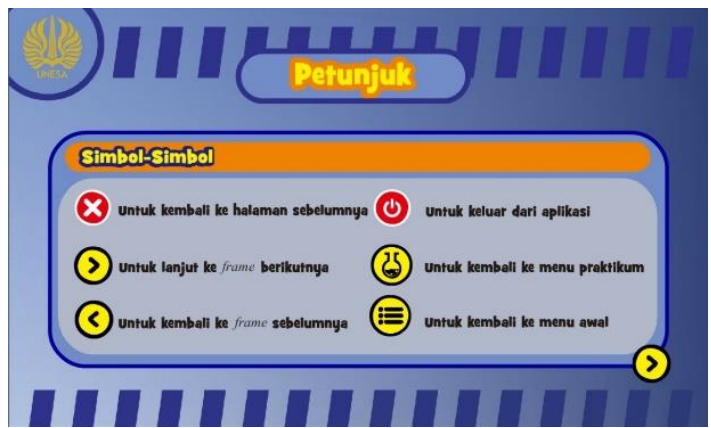

Gambar 4. Menu petunjuk laboratorium virtual

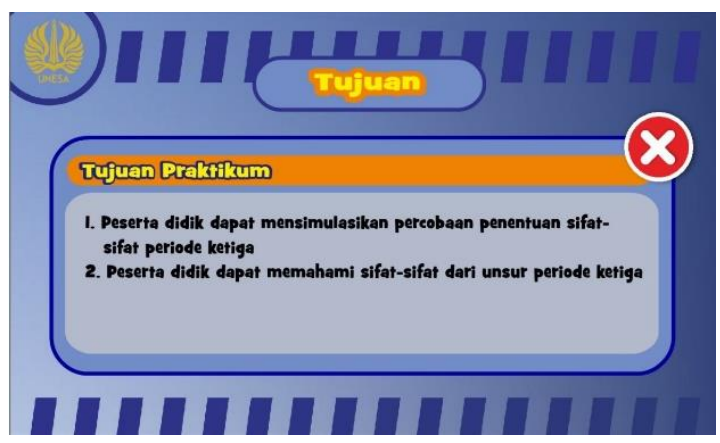

Gambar 5. Menu tujuan laboratorium virtual

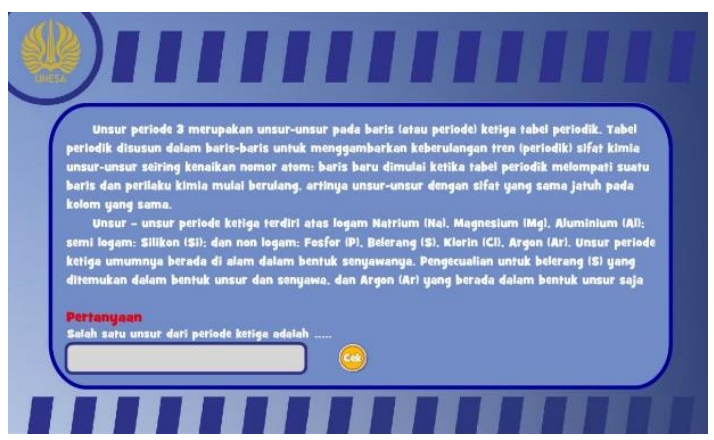

Gambar 6. Menu materi laboratorium virtual

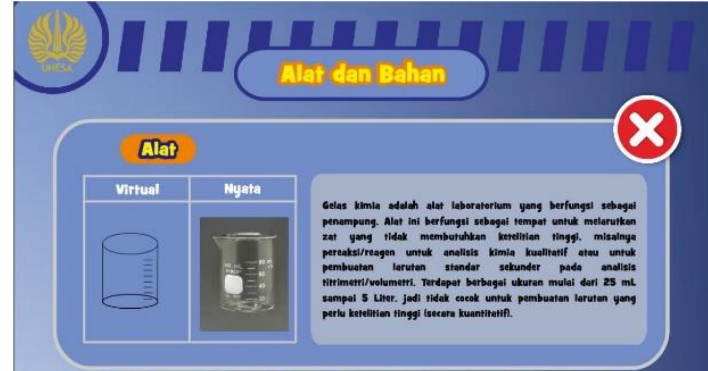

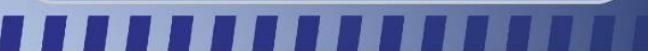

Gambar 7. Menu alat dan bahan laboratorium virtual

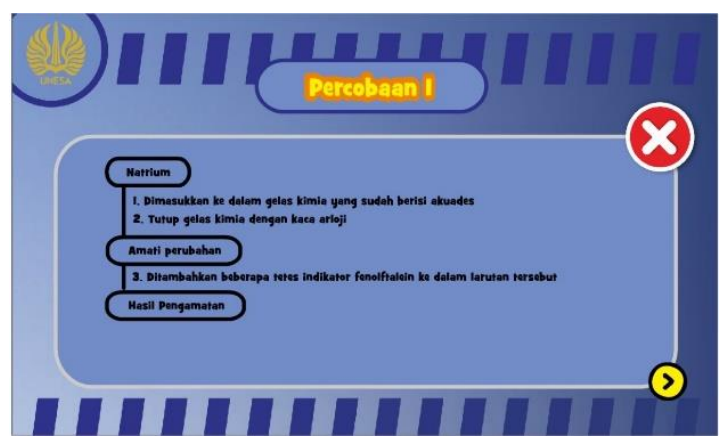

Gambar 8. Menu alur percobaan laboratorium virtual

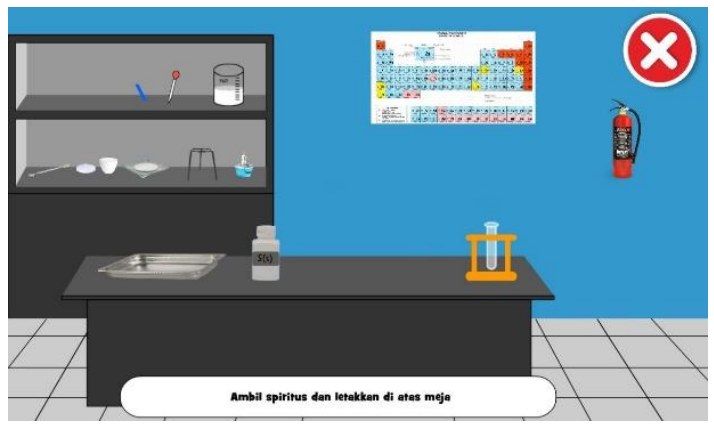

Gambar 9. Tampilan laboratorium virtual

Tahap Pengembangan (Develop)

Tahap pengembangan digunakan untuk memperoleh media pembelajaran yang valid. Media pembelajaran yang valid diperoleh dari hasil revisi yang telah diberi saran dan masukan oleh penelaah, kemudian hasil revisi tersebut diberikan kepada tiga validator yang terdiri atas dua dosen kimia dan satu guru kimia untuk memperoleh hasil bahwa laboratorium virtual pada materi periode ketiga sebagai media pembelajaran telah benar dan ilmu yang disajikan sesuai dengan kaidah ilmu yang benar.

\section{Tahap Validasi}

Validitas media pembelajaran berbasis laboratrium virtual ini ditinjau dari dua aspek yakni validitas isi dan validitas konstruk. Instrumen yang digunakan yakni lembar validasi yang akan diberi penilaian oleh tiga validator 
yakni dua dosen kimia dan satu guru kimia. Pada aspek validitas isi yang dinilai yaitu pada kelayakan isi dari media pembelajaran berbasis laboratorium virtual, sedangkan pada aspek validasi konstruk yang dinilai yaitu pada kelayakan penyajian dan kelayakan bahasa dari media pembelajaran berbasis laboratorium virtual tersebut. Hasil penilaian validasi media pembelajaran berbasis laboratorium virtual materi periode ketiga dapat dilihat pada tabel 4 sebagai berikut:

Tabel 4. Hasil Validasi

\begin{tabular}{cccc}
\hline No & $\begin{array}{c}\text { Aspek } \\
\text { Validitas }\end{array}$ & Persentase & Kriteria \\
\hline 1 & Isi & $85,12 \%$ & $\begin{array}{c}\text { Sangat } \\
\text { Layak } \\
\text { Sangat } \\
\text { Layak }\end{array}$ \\
\hline
\end{tabular}

Dari hasil tersebut dapat diketahui bahwa media pembelajaran berbasis laboratorium virtual yang dikembangkan mendapatkan hasil validasi pada masing-masing aspek yakni pada aspek validasi isi sebesar $84,57 \%$ dan pada aspek validasi konstruk sebesar $87,04 \%$. Hal tersebut berarti bahwa media pembelajaran berbasis laboratorium virtual dapat dikatakan sangat valid. Berikut penjelasan mengenai hasil validitas isi dan validitas konstruk:

\section{Validitas Isi}

Validitas isi memiliki tujuan untuk menilai kesesuaian materi dengan media pembelajaran yang dikembangkan. Dalam aspek validitas isi terdiri atas beberapa kriteria yakni kesesuaian materi yang disajikan dengan tujuan yang hendak dicapai, kesesuaian isi/materi praktikum dengan indikator pembelajaran yang hendak dicapai, kesesuaian/kebenaran konsep yang disajikan. Hasil validasi dari ketiga kriteria tersebut dapat dilihat pada gambar 10 berikut:

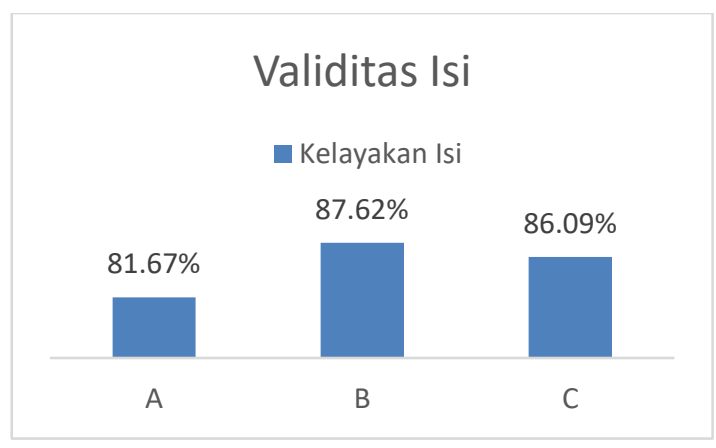

Gambar 10. Diagram hasil penilaian validitas isi
Keterangan:

A : Kesesuaian materi yang disajikan dengan tujuan yang hendak dicapai

B : Kesesuaian isi/materi praktikum dengan indikator pembelajaran yang hendak dicapai

$\mathrm{C}$ : Kesesuaian/kebenaran konsep yang disajikan

Dari diagram di atas dapat diperoleh bahwa hasil validasi isi pada kriteria A yakni kesesuaian materi yang disajikan dengan tujuan yang hendak dicapai memperoleh hasil sebesar 81,67\%, dimana hasil tersebut diinterpretasikan ke dalam tabel 2 maka dapat dikatakan sangat valid. Pada kriteria B yakni keseuaian isi/materi praktikum dengan indikator pembelajaran yang hendak dicapai memperoleh hasil sebesar 87,62\%, dimana hasil tersebut diinterpretasikan ke dalam tabel 2 maka dapat dikatakan sangat valid. Pada kriteria C yakni kesesuaian/kebenaran konsep yang disajikan memperoleh hasil sebesar 86,09\% dan diinterpretasikan ke dalam tabel 2 maka dapat dikatakan sangat valid. Hasil keseluruhan atau hasil rata-rata yang diperoleh dari validitas isi sebesar $85,12 \%$, dimana jika hasil tersebut diinterpretasikan ke dalam tabel 2 maka termasuk ke dalam kategori sangat valid. Hal tersebut berarti bahwa validasi isi dari media pembelajaran berbasis laboratorium virtual dikatakan sangat layak.

Pada aspek validitas isi, media pembelajaran dikatakan layak apabila memuat kebenaran konsep yang disajikan dalam segi materi. Hal yang diperhatikan dalam aspek validitas isi yaitu kompetensi dasar dan indikator pembelajaran terdapat keterkaitan dengan materi yang disajikan. Menurut (Arsyad, 2014) menyatakan bahwa suatu media pembelajaran diharuskan fokus terhadap tujuan pembelajaran yang mencakup kemampuan peserta didik yang diharapkan setelah proses pembelajaran dilakukan. Selain itu, materi yang digunakan juga harus berisi data yang akurat dan tidak menyebabkan miskonsepsi.

\section{Validitas Konstruk}

Validitas konstruk memperhatikan aspek konstruk dari media pembelajaran. Dalam aspek validitas konstruk terbagi menjadi dua, meliputi validitas penyajian dan validitas bahasa. Penjelasan lebih rinci mengenai kedua aspek tersebut akan dijelaskan sebagai berikut:

\section{Aspek Penyajian}

Dalam aspek penyajian memiliki tujuan untuk menilai kejelasan media pembelajaran berbasis laboratorium virtual yang 
dikembangkan. Dalam aspek penyajian terdiri atas beberapa kriteria yakni materi pada media disajikan secara sistematis, ilustrasi yang disajikan jelas, relevan, serta dapat membantu peserta didik untuk lebih mudah memahami materi, format penyajian materi dan ilustrasi menarik sehingga dapat memotivasi peserta didik, kualitas penyajian materi dalam segi tata letak, ukuran, warna, dan pencahayaan, serta petunjuk pengoperasian media telah jelas dan lengkap. Hasil validasi dari kelima kriteria dalam aspek penyajian tersebut dapat dilihat pada gambar 11 berikut:

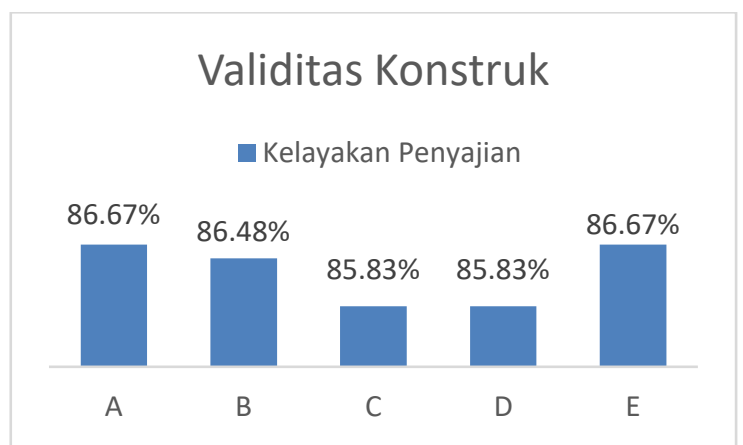

Gambar 11. Diagram hasil penilaian

kelayakan penyajian dalam validitas konstruk Keterangan:

A : materi pada media disajikan secara sistematis.

B : ilustrasi yang disajikan jelas, relevan, serta dapat membantu peserta didik untuk lebih mudah memahami materi.

C : format penyajian materi dan ilustrasi menarik.

D : kualitas penyajian materi dalam segi tata letak, ukuran, warna, dan pencahayaan.

E : petunjuk pengoperasian media telah jelas dan lengkap.

Dari diagram di atas dapat diperoleh bahwa hasil kealayakan penyajian dalam validitas konstruk pada kriteria A yakni materi pada media disajikan secara sistematis memperoleh hasil sebesar 86,67\%, dimana hasil tersebut diinterpretasikan ke dalam tabel 2 maka dapat dikatakan sangat valid. Pada kriteria B yakni ilustrasi yang disajikan jelas, relevan, serta dapat membantu peserta didik untuk lebih mudah memahami materi memperoleh hasil sebesar $86,48 \%$, dimana hasil tersebut diinterpretasikan ke dalam tabel 2 maka dapat dikatakan sangat valid. Pada kriteria $\mathrm{C}$ yakni format penyajian materi dan ilustrasi menarik sehingga dapat memotivasi peserta didik memperoleh hasil sebesar $85,53 \%$, dimana hasil tersebut diinterpretasikan ke dalam tabel 2 maka dapat dikatakan sangat valid. Pada kriteria D yakni kualitas penyajian materi dalam segi tata letak, ukuran, warna, dan pencahayaan memperoleh hasil sebesar 85,53\%, dimana hasil tersebut diinterpretasikan ke dalam tabel 2 maka dapat dikatakan sangat valid. Pada kriteria E yakni petunjuk pengoperasian media telah jelas dan lengkap memperoleh hasil sebesar 86,67\% dan diinterpretasikan ke dalam tabel 2 maka dapat dikatakan sangat valid. Hasil keseluruhan atau hasil rata-rata yang didapatkan dari aspek penyajian sebesar $86,18 \%$, dimana jika hasil tersebut diinterpretasikan ke dalam tabel 2 maka termasuk ke dalam kategori sangat valid. Hal tersebut berarti bahwa aspek penyajian dalam validitas konstruk dari media pembelajaran berbasis laboratorium virtual dinilai sangat layak.

Media pembelajaran berbasis laboratorium virtual yakni media berbasis visual yang bermanfaat untuk membantu proses pembelajaran dan diharapkan dapat mempengaruhi proses belajar menjadi lebih baik. Penerapan teori kognitif dalam media pembelajaran berbasis laboratorium virtual dengan menyajikan materi dalam bentuk gambar, ataupun teks dalam tampilan yang variatif, sehingga pemahaman peserta didik meningkat dalam memahami konsep dan dapat disimpan dalam memori jangka panjang (Dwiningsih dkk., 2018). Motivasi peserta didik meningkat apabila menggunakan media pembelajaran laboratorium virtual. Hal tersebut didukung oleh pernyataan Levie \& Lentz (1982) bahwa media pembelajaran yang bersifat visual dapat menarik minat peserta didik supaya memiliki konsentrasi yang tingggi terhadap materi yang dibahas. Ketertarikan peserta didik terhadap media pembelajaran dimungkinkan dapat mencapai tujuan belajar (Purnomo dkk., 2016).

\section{Aspek Bahasa}

Dalam aspek bahasa memiliki tujuan untuk menilai penggunaan bahasa yang mudah untuk dipahami dalam media pembelajaran berbasis laboratorium virtual yang dikembangkan. Dalam aspek bahasa terdiri atas beberapa kriteria yakni penggunaan ejaan bahasa Indonesia yang benar, penggunaan bahasa/istilah/simbol/ lambang yang jelas, relevan, dan mudah dipahami, menggunakan bahasa/istilah/simbol/ lambang secara konsisten, penggunaan kalimat yang sederhana dan mudah dipahami, menggunakan kalimat yang jelas sehingga tidak menimbulkan penafsiran ganda, kesesuaian bahasa yang digunakan dengan usia peserta didik, serta 
terdapat keruntutan antar kalimat maupun antar paragraf. Hasil validasi dari kelima kriteria dalam aspek bahasa tersebut dapat dilihat pada gambar 12 berikut:

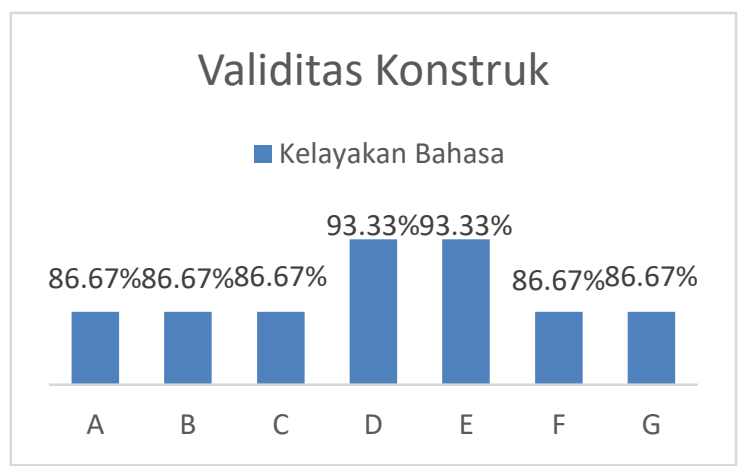

Gambar 12. Diagram penilaian kelayakan bahasa dalam validitas konstruk

Keterangan:

A : penggunaan ejaan bahasa Indonesia yang benar

B : menggunakan bahasa/istilah/simbol/ lambang yang jelas, relevan, dan mudah dipahami

C : menggunakan bahasa/istilah/simbol/ lambang secara konsisten

D : penggunaan kalimat yang sederhana dan mudah dipahami

$\mathrm{E}$ : penggunaan kalimat yang jelas dan tidak menimbulkan penafsiran ganda

$\mathrm{F}$ : kesesuaian bahasa yang digunakan dengan usia peserta didik

$\mathrm{G}$ : terdapat keruntutan antar kalimat maupun antar paragraf

Dari diagram di atas dapat diperoleh bahwa hasil kelayakan bahasa dalam validitas konstruk pada kriteria A yakni ketepatan penggunaan ejaan bahasa Indonesia yang benar memperoleh hasil sebesar 86,67\%, dimana hasil tersebut diinterpretasikan ke dalam tabel 2 maka dapat dikatakan sangat valid. Pada kriteria B yakni menggunakan bahasa/istilah/simbol/ lambang yang jelas, relevan, dan mudah dipahami memperoleh hasil sebesar $86,67 \%$, dimana hasil tersebut diinterpretasikan ke dalam tabel 2 maka dapat dikatakan sangat valid. Pada kriteria C yakni menggunakan bahasa/istilah/simbol/ lambang secara konsisten memperoleh hasil sebesar $86.67 \%$, dimana hasil tersebut diinterpretasikan ke dalam tabel 2 maka dapat dikatakan sangat valid. Pada kriteria D yakni menggunakan kalimat yang sederhana dan mudah dipahami memperoleh hasil sebesar $93,33 \%$, dimana hasil tersebut diinterpretasikan ke dalam tabel 2 maka dapat dikatakan sangat valid. Pada kriteria E yakni penngunaan kalimat jelas dan tidak menimbulkan penafsiran ganda memperoleh hasil sebesar $93,33 \%$, dimana hasil tersebut diinterpretasikan ke dalam tabel 2 maka dapat dikatakan sangat valid. Pada kriteria F yakni kesesuaian bahasa yang digunakan dengan usia peserta didik memperoleh hasil sebesar $86.67 \%$, dimana hasil tersebut diinterpretasikan ke dalam tabel 2 maka dapat dikatakan sangat valid.Pada kriteria $G$ yakni terdapat keruntutan antar kalimat maupun antar paragraf memperoleh hasil sebesar 86,67\% dan diinterpretasikan ke dalam tabel 2 maka dapat dikatakan sangat valid. Hasil keseluruhan atau hasil rata-rata yang diperoleh dari aspek bahasa sebesar 88,89\%, dimana jika hasil tersebut diinterpretasikan ke dalam tabel 2 maka termasuk ke dalam kategori sangat valid. Hal tersebut berarti bahwa aspek bahasa dalam validitas konstruk yang digunakan dalam media pembelajaran berbasis laboratorium virtual dikatakan sangat layak.

Media pembelajaran berbasis laboratorium virtual ini berfungsi sebagai alat bantu komunikasi guru terhadap peserta didik sehingga tata bahasa yang digunakan dalam media harus diperhatikan (Dwiningsih dkk., 2018). Bahasa yang digunakan dalam media tidak diperbolehkan mengandung makna ganda dan harus sesuai dengan ejaan bahasa Indonesia yang baik dan benar, serta sesuai dengan karakteristik peserta didik. Hal tersebut supaya peserta didik dapat memahami pesan yang ingin disampaikan. Berdasarkan uraian tersebut berarti bahasa yang digunakan dalam media laboratorium virtual telah sesuai dengan ejaan yang baik dan benar sehingga media pembelajaran dikatakan valid dalam aspek kebahasaan.

\section{Tahap Uji Coba Awal}

Pada tahap uji coba, peneliti melakukan uji coba produk terhadap 12 peserta didik MA AlMadany di Gresik yang bertujuan untuk mengetahui keefektifan media pembelajaran berbasis laboratorium virtual yang dikembangkan.

Keefektifan media pembelajaran berbasis laboratorium virtual yang dapat diketahui berdasarkan hasil belajar peserta didik. Metode yang digunakan yakni one-group-pretest-andposttest dengan menggunakan 10 soal pilihan ganda mengenai sifat-sifat unsur periode ketiga. Soal yang diberikan berada pada rentang aspek kognitif C1, C2, C3, dan C4. Soal pretest diberikan sebelum peserta didik menggunakan media pembelajaran berbasis laboratorium virtual, sedangkan soal posttest diberikan ketika 


\section{Chemistry Education Practice, 4 (2), 2021 - 169}

Dzikro, Dwiningsih

peserta didik telah menggunakan media pembelajaran berbasis laboratorium virtual. Keefektifan ditinjau dari peningkatan hasil belajar peserta didik. Peningkatan hasil belajar peserta didik diperoleh dari perhitungan skor $N$ gain. Hasil belajar peserta didik dapat dilihat pada tabel 5 berikut:

Tabel 5. Hasil pretest posttest

\begin{tabular}{|c|c|c|c|c|}
\hline Nama & Pretest & Posttest & $N$-gain & Kategori \\
\hline AAHR & 70 & 100 & 1 & Tinggi \\
\hline ARS & 70 & 100 & 1 & Tinggi \\
\hline APSA & 60 & 90 & 0.75 & Tinggi \\
\hline $\mathrm{AF}$ & 80 & 100 & 1 & Tinggi \\
\hline DNA & 40 & 90 & 0.833333 & Tinggi \\
\hline EK & 40 & 90 & 0.833333 & Tinggi \\
\hline HS & 90 & 100 & 1 & Tinggi \\
\hline INH & 30 & 90 & 0.857143 & Tinggi \\
\hline LNR & 50 & 90 & 0.8 & Tinggi \\
\hline MR & 40 & 90 & 0.833333 & Tinggi \\
\hline RM & 60 & 90 & 0.75 & Tinggi \\
\hline SY & 50 & 90 & 0.8 & Tinggi \\
\hline
\end{tabular}

bahwa skor $\mathrm{N}$-gain dari 12 peserta didik MA AlMadany diperoleh pada rentang 0,75-1 atau 75$100 \%$ yang dapat dikategorikan pada kategori tinggi sehingga media pembelajaran berbasis laboratorium virtual sub materi kimia unsur periode ketiga dapat dikatakan sebagai media pembelajaran yang efektif.

Berdasarkan hasil penelitian mengenai keefektifan media pembelajaran dapat dijelaskan bahwa pembelajaran materi kimia unsur periode ketiga dengan menggunakan media pembelajaran laboratorium virtual dapat menjadikan peserta didik lebih aktif dalam proses belajar. Suasana kelas yang tercipta terlihat lebih hidup dan peserta didik terlihat lebih bersemangat. Hal tersebut berarti bahwa peserta didik lebih tertarik terhadap penggunaan laboratorium virtual sebagai media pembelajaran sehingga dapat berpengaruh terhadap hasil belajar peserta didik.

Hasil di atas relevan dengan hasil penelitian sebelumnya yakni penelitian oleh (Siregar, 2017) yang dimana hasil belajar peserta didik mengalami peningkatan dengan bantuan media pembelajaran. Penelitian lain oleh (Dwiyanti dkk., 2019) menyatakan bahwa penggunaan laboratorium virtual sebagai media pembelajaran berpengaruh terhadap hasil belajar peserta didik dapat meningkat. Penelitian tersebut menjelaskan bahwa aspek makroskopis, submikroskopis, dan simbolik lebih mudah untuk dipahami apabila menggunakan laboratorium virtual (Dalton, 2016).

\section{SIMPULAN}

Berdasarkan hasil penelitian dan analisis data pada pengembangan media pembelajaran berbasis laboratorium virtual sub materi periode ketiga dapat disimpulkan bahwa media pembelajaran berbasis laboratorium virtual layak untuk digunakan sebagai media pembelajaran. Hal tersebut dikarenakan laboratorium virtual yang dikembangkan memenuhi syarat kelayakan meliputi kevalidan dan keefektifan.

\section{DAFTAR PUSTAKA}

Alponita, F. (2018). Pengembangan Media Pembelajaran Berbasis Laboratorium Virtual Menggunakan Macromedia Flash pada Praktikum Reaksi Alkali dan Alkali Tanah di Kelas XII SMA. Repository Universitas Jambi, 14(3), 37-45.

Arham, U. U., \& Dwiningsih, K. (2016). Kelayakan Multimedia Interaktif Berbasis Blended Learning pada Materi Pokok Kimia Unsur. UUNESA Journal of Chemical Education, 5(2), 345-352.

Arsyad, A. (2014). Media Pembelajaran dalam Pendidikan. Jakarta: PT Raja Grafindo Persada.

Chen, C., Jones, K. T., \& Xu, S. (2018). The Association Between Students' Style of Learning Preferences, Social Presence, Collaborative Learning and Learning Outcomes. Journal of Educators Online, 15(1). https://doi.org/10.9743/JEO2018.15.1.3

Dalton, M. A. P. L. V. (2016). General Chemistry 1045 Laboratory Manual. In Virginia Polytechnic Institute and State University.

Dwiningsih, K., Sukarmin, Nf., Muchlis, Nf., \& Rahma, P. T. (2018). Pengembangan Media Pembelajaran Kimia Menggunakan Media Laboratorium Virtual Berdasarkan Paradigma Pembelajaran Di Era Global. Kwangsan: Jurnal Teknologi Pendidikan, 6(2), 156-176. https://doi.org/10.31800/jtp.kw.v6n2.p156$-176$

Dwiyanti, A. N., Riwanto, M. A., \& Budiarti, W. N. (2019). Penerapan Laboratorium Virtual Sebagai Upaya Meningkatkan Hasil Belajar dan Karakter Pada Siswa Kelas IV SDN 1 Tambaknegara Tahun Ajaran 2019/2020. Jurnal Pancar, 3(2), 275-278.

Hake, R. R. (1998). Interactive-Engagement 
Versus Traditional Methods: A SixThousand-Student Survey of Mechanics Test Data For Introductory Physics Courses. American Journal of Physics. https://doi.org/10.1119/1.18809

Herga, N. R., Cagran, B., \& Dinevski, D. (2016). Virtual Laboratory in the Role of Dynamic Visualisation for Better Understanding of Chemistry in Primary School. Eurasia Journal of Mathematics, Science and Technology Education. https://doi.org/10.12973/eurasia.2016.1224 a

Ibrahim. (2015). Metode Penelitian Kualitatif. Bandung: Alfabeta.

Levie, W. H., \& Lentz, R. (1982). Effects of Text Illustrations: A Review of Research. Educational Communication \& Technology. https://doi.org/10.1007/BF02765184

Mangengke, B. B., \& Dwiningsih, K. (2020). Validitas Media Pembelajaran Berbasis Laboratorium Virtual pada Sub Materi Kimia Unsur Aluminium. 9(1), 71-78.

Mangengke, B. B., \& Dwiningsih, K. (2021). Pembelajaran Kimia Berbasis Kooperatif Think Pair Share(Tps) Dengan Berbantuan Virtual Laboratorium Untuk Meningkatkan Hasil Belajar Siswa. 15(1), 2706-2716.

Purnomo, A., Ratnawati, N., \& Aristin, N. F. (2016). Pengembangan Pembelajaran Blended Learning Pada Generasi Z. Jurnal Teori Dan Praksis Pembelajaran IPS, 1(1), 70-77.

https://doi.org/10.17977/um022v1i12016p 070

Raffani Ovianti, A., P., \& Dwiningsih, K. (2016). Developing Multimedia Interactive Based Blended Learning at Kimia Subject Class XII. Proceedings of International Research Clinic \& Scientific Publications of Educational Technology, 2010, 324-337.

Riduwan. (2010). Skala Pengukuran Variabelvariabel Penelitian. Bandung: Alfabeta.

Setiawan, B., \& Dwiningsih, K. (2020). Validitas Virtual Lab sebagai Media Pembelajaran pada Materi Kimia Unsur Sub Materi Hidrogen. UNESA Journal of Chemical Education, 9(1), 115-120.

Setiawan, E. (2019). KBBI - Kamus Besar Bahasa Indonesia. Jakarta: Balai Pustaka.

Siregar, E. M. (2017). Pengaruh Penerapan Laboratorium Virtual terhadap Hasil Belajar Siswa pada Materi Larutan Asam Basa Kelas XI MIA MAN Model Kota
Jambi. Repository Universitas Jambi. http://repository.unja.ac.id/2250/1/Artikel Eka Muharyani Siregar.pdf

Slavin, R. E. (2009). Educational Psychology: Theory and Practice. New Jersey: Pearson Education.

Sugiyono. (2013). Metode Penelitian Pendidikan Pendekatan Kuantitaif, Kualitatif, dan $R \& D$. Bandung: Alfabeta. 